\title{
Deltonin induced both apoptosis and autophagy in head and neck squamous carcinoma FaDu cell
}

\author{
Y. L. XIE ${ }^{1, \star}$, M. FAN ${ }^{2}$, R. M. JIANG ${ }^{2}$, Z. L. WANG ${ }^{3}, \mathrm{Y}^{2} \mathrm{LI}^{3}$
}

${ }^{1}$ Department of Otorhinolaryngology, West China Hospital of Sichuan University, Chengdu, Sichuan, China 610041; ${ }^{2}$ Departmen of Otorhinolaryngology, the 7th Hospital of Chengdu City, Chengdu, Sichuan, China 610041; ${ }^{3}$ State Key Laboratory of Biotherapy and Cancer Center, West China Hospital of Sichuan University, Chengdu, Sichuan, China 610041

*Correspondence: yaliu_xie@163.com

Received June 25, 2014 / Accepted November 19, 2014

For decades, despite the advancement of medical science, the prognosis of head and neck squamous cell carcinoma (HNSCC), has not improved. Deltonin is one of the major active components of Dioscorea Zingiberensis Wright that has been used for anthrax, rheumatic heart disease, rheumatoid arthritis etc. By employing HNSCC FaDu cell and normal human epidermal keratinocyte, we investigate deltonin efficacy and associated mechanism in both cell culture and nude mice xenografts. Deltonin treatment selectively prevents proliferation of $\mathrm{FaDu}$ cells by cell-cycle arrest and induction of apoptosis, via activating checkpoint kinase Chk1and Chk2 as well as caspases 8, 9 and 3. Meanwhile, we found that treatment with deltonin induced autophagy, which played a protective role against deltonin-induced apoptosis. Further studies revealed that deltonin activated autophagy by Akt-mTOR signaling. Additionally, xenograft model showed that administration of deltonin significantly inhibited tumor growth and prolonged survival of tumor bearing mice. Our studies suggested that deltonin might be a potential chemotherapeutic agent against HNSCC, which might contribute to clinical application and pharmacological study of deltonin in future anti-cancer research.

Key words: deltonin, anti-tumor, head and neck squamous cell carcinoma, apoptosis, autophagy

Almost all (95\%) head and neck cancers are squamous cell carcinomas (HNSCC)[1]. HNSCC is the sixth most common type of cancer and cancer-related death that accounts for $6 \%$ of all cancer cases [2-3]. Current standard therapy options for HNSCC patients contains surgery, radiation, and chemotherapy, which undergoing multiple significant progresses in recent years. However, in the last three decades, the mortality rate of HNSCC is still high (5-year survival rate is less than 50\%). In addition, although some patients are clinically cured, the survivors usually suffer voice disorder and dysphagia caused by surgery and radiotherapy-the most commonly used treatments for HNSCC [4]. To improve prognoses and the patients' quality life, it is urgent to develop more reliable and safer treatments for patients with HNSCC.

Many evidence-based medicines are originally derived from extracts of traditional medical plants; it is therefore reasonable to suppose that investigations in this area may offer fruitful and relatively inexpensive sources of possible treatments [5].
Deltonin (diosgenin-3-O- $\beta$-d-glucopyranosyl $(1 \rightarrow 4)$ - $[\alpha-1-$ rhamnopyranosyl $(1 \rightarrow 2)]-\beta$-d-glucopyranoside) is a major spirostanol glycoside constituent in Dioscorea Zingiberensis C.H. Wright (DZW), an important and widely used traditional Chinese medicine. As a widely distributed plant in China, DZW in nature have a variety of interesting biological activities and its rhizome has been used as a traditional Chinese medicine for anthrax, rheumatic heart disease, rheumatoid arthritis etc [6]. Steroidal saponins are identified as the major active components of DZW, including zingiberensis new saponin, diosgenin, trillin, gracillin [7-8]. Among these steroidal saponins, deltonin is one of the two main constituents [9]. In its chemical structure, diosgenin-3-O- $\beta$-D-glucopyranosyl $(1 \rightarrow 4)$ [ $\alpha$-L-rhamnopyranosyl $(1 \rightarrow 2)]-\beta$-D-glucopyranoside, is a large hydrophobic structure contributes to transportation across the cell membrane, while the sugar moiety determines hydrophilicity [10]. Recently, many reports showed that deltonin elicited an anti-tumor effect in several tumor cell lines, including SKOV3, B16, PC-3, LL2, CT26, A549 and MDA- 


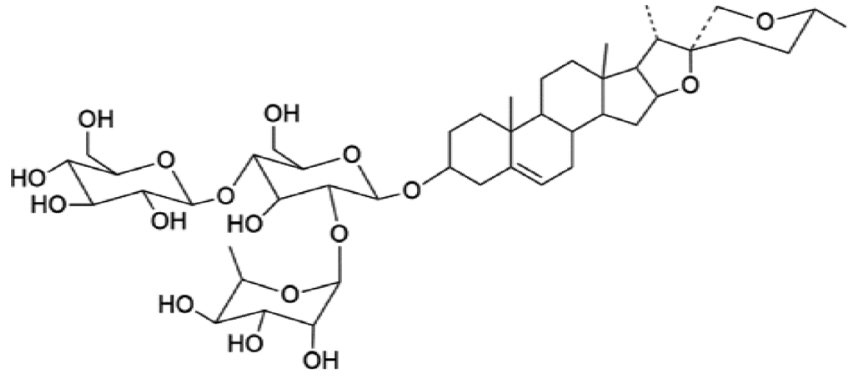

\section{Deltonin:diosgenin-3-O- $\beta-D-$ glucopyranosyl $(1 \rightarrow 4)-[\alpha-L$ -rhamnopyranosyl ( $1 \rightarrow 2)$ ]- $\beta$-D-glucopyranoside}

Figure 1. Chemical structure of deltonin, diosgenin-3-O- $\beta$-D-glucopyranosyl $(1 \rightarrow 4)$-[ $\alpha$-L-rhamnopyranosyl $(1 \rightarrow 2)]$ - $\beta$-D-glucopyranoside

MB-231[11], but its anti-tumor spectrum is still limited and the mechanism remains unclear.

Autophagy is a highly regulated homeostatic process involved in turnover of long-lived proteins and whole organelles by lysosomal activity that eliminates excess or damaged organelle and some pathogens [12]. The formation of double-membrane autophagosome initiated by PI3 kinase type III-Atg6/Beclin 1 cascade is the main characteristic of autophagy [13]. Formation and expansion of the autophagosome are mediated by two ubiquitin-like conjugation systems: the Atg8/LC3 -phosphatidylethanolamine conjugate system and the Atg12-Atg5 conjugate system[14]. Autophagy signaling can be activated by multiple signaling pathways in response to numerous forms of cellular stress including hypoxia, starvation, chemical insults or radiation [15]. Of them, the Akt-mTOR signaling pathway is considered as a classic negative regulator of autophagy by initiation of the vesicular double-membrane formation [16]. The molecular crosstalk between apoptotic and autophagic signaling pathway is complicated. Both pathways share several same or relational genes that are critical for their respective function [17]. It has been reported that Atg5, which is indispensable in autophagosome formation, switches autophagy to apoptosis response to death stimuli $[18,19]$. In addition, Bcl-2 and Bcl-xL, 2 typical apoptosis negative regulators, can retard autophagy progression by binding to the $\mathrm{BH} 3$ domain of Beclin 1[20].

In the present study, we aimed to use isolated deltonin from DZW and investigated its roles in antagonizing HNSCC. We evaluated its effects against hypopharyngeal carcinoma cell line $\mathrm{FaDu}$ as indicated by proliferation, cell-cycle arrest in G2/M phase, apoptosis, and autophagy induced by apoptosis. We observed a hitherto undescribed cellular response of deltonin-induced protective autophagy in FaDu cells, and this process was mediated by modulation of Akt-mTOR signaling. In vivo, intraperitoneal administration of deltonin significantly inhibited the tumor growth and prolonged survival of the
FaDu tumor-bearing mice. Our studies could provide the groundwork for future studies on the implication of autophagy in deltonin-mediated anticancer activities.

\section{Materials and methods}

Chemical and reagents. The deltonin was provided from the Institute for Nanobiomedical Technology and Membrane Biology of Sichuan University (Chengdu, Sichuan, China); its purity, as determined by HPLC, was above $98 \%$; its architecture is shown in Figure 1. GAPDH antibody, 3-[4, 5-dimethylthiazol-2-yl]-2, 5-diphenyltetrazolium (MTT), dimethylsulfoxide (DMSO), FITC-dextran and tamoxifen (TAM) were purchased form Sigma Aldrich St. Louis, MO, USA. Primary antibodies against were purchased from the following sources: checkpoint kinase $1 / 2(\mathrm{Chk} 1 / 2)$ were from Santa Cruz Biotechnology (Santa Cruz, CA). Phospho-Chk1 (Ser296 and Ser345), phospho-Chk2 (Thr68), caspase-3, caspase-9, Bcl-2, Akt, phosphor-Akt, caspase-8, Erk1/2 and p-Erk1/2 (Cell Signaling Technology, Beverly, MA, USA), Beclin 1, $\beta$-actin (Santa Cruz, CA, USA), Atg5, Atg7 (Abcam, Cambridge, MA, USA), mTOR, phospho-mTOR (Millipore Corporation, Bedford, MA, USA), secondary antibodies were obtained from Santa Cruz Biotechnology, Inc. (Santa Cruz, CA, USA).

Cell culture. Human hypopharyngeal carcinoma cell line $\mathrm{FaDu}$, was obtained from the American Type Culture Collection (ATCC). Cells were cultured in RPMI 1640 medium (Life Technologies, Bedford, MA, USA) supplemented with 10\% fetal bovine serum (FBS; Gibco, Auckland, New Zealand), 1 $\mathrm{mmol} / \mathrm{L}$ sodium pyruvate, $50 \mathrm{\mu g} / \mathrm{mL}$ streptomycin, and $50 \mathrm{U} /$ $\mathrm{mL}$ penicillin at $37^{\circ} \mathrm{C}$ in an atmosphere of $5 \% \mathrm{CO}_{2}$. Normal human epidermal keratinocytes were purchaseed from ScienCell (USA) and cultured Clonetics ${ }^{\mathrm{TM}} \mathrm{KGM}^{\mathrm{TM}}$ Keratinocyte Growth Medium (Lonza, USA).

Cell viability assay (MTT dye assay). The cytotoxicity of deltonin on hypopharyngeal carcinoma cells was determined by MTT assay. FaDu cells were seeded at a density of $5 \times 10^{3}$ per well in 96-well plates (Costar Corning, Rochester, NY, USA). After $24 \mathrm{~h}$ incubation, cells were treated with deltonin in various concentrations $(0.5,1,2$, or $5 \mu \mathrm{M})$; vehicle DMSO $(<0.05 \%)$ was used as a control. Five wells were used for each concentration. At 24, 48 and $72 \mathrm{~h}$, the absorbance at $570 \mathrm{~nm}$ was measured with SpectraMax M5 (Molecular Devices, Sunnyvale, CA, USA), using wells without cells as blanks. All experiments were performed in triplicate. The concentration- and time-dependent curves of the deltonin-treated hypopharyngeal cancer cell lines were generated as the percent cell growth inhibition, using the following formula: the cell inhibitory rate $=([$ control cell A570] $-[$ treated cell A570] $) /$ [control cell A570] $\times 100 \%$. The $50 \%$ inhibiting concentration $\left(\mathrm{IC}_{50}\right)$ was calculated by SPSS for windows software version 16.0 (IBM, USA).

Cell cycle and apoptosis assays. Flow cytometry was used to analyze cell cycle arrest and apoptosis induction effect of 
deltonin as previously described[21, 22]. Briefly, $2 \times 10^{5} \mathrm{FaDu}$ cells were cultured in $2 \mathrm{~mL}$ of medium/well in 6-well plates (Costar Corning, Rochester, NY, USA). According to the results of previous MTT screening, after overnight incubation, the cells were treated with 1,2 or $5 \mu \mathrm{mol} / \mathrm{L}$ (both for apoptosis analysis and cell-cycle analysis) of deltonin; vehicle DMSO (< $0.05 \%$ ) was used as control. After $24 \mathrm{~h}$, for cell-cycle analysis, cells were harvested by trypsinization, fixed with $70 \%$ ethanol at $4^{\circ} \mathrm{C}$ overnight, stained with propidium iodide and analyzed by FAC Sort cytometer (ESP Elite, Beckman Coulter, Fullerton, CA.). The apoptotic index was assessed using Annexin V-FITC Apoptosis kit, following the protocol provided by the manufacturer.

Western blot analysis. Cells $\left(2.5 \times 10^{5}\right)$ were seeded in 6-well plates (Costar Corning, Rochester, NY, USA). After $24 \mathrm{~h}$, the cells were incubated with various concentrations of deltonin $(0,1 \mu \mathrm{M}, 2 \mu \mathrm{M}$ or $5 \mu \mathrm{M})$ for $48 \mathrm{~h}$, or with deltonin of $5 \mu \mathrm{M}$ for different times ( $24 \mathrm{~h}, 48 \mathrm{~h}$ or $72 \mathrm{~h}$ ). Proteins were extracted on ice in radio immunoprecipitation assay (RIPA) lysis buffer (Beyotime, Shanghai, China) with protease inhibitor (Roche Diagnostics, Basel, Switzerland). Equal amounts of protein (40 $\mu \mathrm{g})$ in the cell extracts were fractionated by $12 \%$ SDS-PAGE denaturing gels using Mini-Protean Bio-Rad II System (BioRad, Hercules, CA, USA), and then transferred onto PVDF membrane (Bio-Rad, Hercules, CA, USA). Membranes were blocked in $20 \mathrm{mM}$ Tris-buffered saline-0.1\% Tween (TBST) buffer containing $5 \%$ non-fat milk at room temperature for 1 $\mathrm{h}$, and then probed with specific primary antibodies overnight at $4{ }^{\circ} \mathrm{C}$. After washing with TBST for $45 \mathrm{~min}$, membranes were incubated with an appropriate peroxidase-conjugated secondary antibody for $1 \mathrm{~h}$ at room temperature. Finally, immunoblot signals were visualized using enhanced chemiluminescence (Millipore, Bedford, MA, USA). Densitometry readings for three independent blots were taken with Quantity One software (Bio-Rad, Hemel Hempstead, Herts, UK) for statistical analysis.

In vivo nude mice FaDu xenograft assay. The tumor model we used in this study has been described previously [23]. Briefly, $5 \times 10^{6} \mathrm{FaDu}$ cells per $0.2 \mathrm{ml}$ were s.c. injected into 4- to 6-wk-old nude mice (Beijing HFK Bioscience Co,. LTD, Beijing, China). All experiments conformed to the animal care and use guidelines of the Institute's Animal Care and Use Committee of Sichuan University. The mice were randomly divided into three groups of 10 mice. One week after $\mathrm{FaDu}$ implantation, the treatment groups received their first doses of deltonin dissolved in a vehicle $(0.5 \%$ carboxy methylcellulose/0.1\% Tween-80) (Sigma-Aldrich, USA) in saline solution. Deltonin dosage and administration schedules were based on our preliminary toxicologic and pharmacokinetic studies[24]. Briefly, deltonin was given via intraperitoneal administration to tumor-bearing mice at 40 and $80 \mathrm{mg} / \mathrm{kg}$ every day for 3 weeks (between day 8 and 28). In parallel, the control group received the vehicle. General clinical observations of the mice, including determination of body weight and tumor growth, were made every three days. Tumor size was measured by the modified ellipsoid formula: $(\pi / 6) \times \mathrm{AB}^{2}$, where $\mathrm{A}$ is the longest and $\mathrm{B}$ is the shortest perpendicular axis of an assumed ellipsoid corresponding to tumor mass [25]. The mice were humanely euthanized when they became moribund, as defined by: weight loss $>10-15 \%$, lethargy or ruffled fur. The sacrifice date was recorded to calculate the survival time. For detection of toxicity effects of deltonin on mice, deltonin $(80 \mathrm{mg} / \mathrm{kg})$ was intraperitoneal administered to Balb/c mice once per day for 8 weeks.

Terminal deoxynucleotidyl transferase-mediated dUTPnick-end labeling detection. The Terminal deoxynucleotidyl transferase-mediated dUTP nick-end labeling (TUNEL) assay was performed to study DNA fragmentation in ex vivo-incubated FaDu cells or tumor tissue. Analysis of apoptotic cells in ex vivo-incubated FaDu cells was performed using an apoptotic cell detection kit following the manufacturer's directions (Promega, Madison, Wisc., USA). To analyze apoptotic processes in tumor tissues, TUNEL staining was performed using the In Situ Cell Death Detection Kit (Roche Diagnostics) on paraffin-embedded tissue harvested from tumors per manufacturer's instructions. DAPI counterstain was used to identify cells with intact nuclei. TUNEL-positive cells had pyknotic nucleus with dark green fluorescent staining, pointed apoptosis. All fluorescence imaging was performed and digitally captured at $\times 100$ magnification on a fluorescent microscope (Olympus, Tokyo, Japan).

Data analysis and reproducibility. Statistical analysis was performed with the SPSS software system (SPSS for Windows, version 13.0; SPSS Inc, Chicago, IL). The data of cell cycle distribution, cell apoptosis, cell viability and TUNEL-positive cells were analyzed by one-way ANOVA followed by post hoc tests. Non-parametric Mann-Whitney U-test was used to compare the data of quantifying bands on western blot. Survival curves were statistically analyzed using Kaplan-Meier test. Data were expressed as means \pm S.E. A $P$ value $<0.05$ or $<0.01$ was considered significant.

\section{Results}

Cytotoxic effects of deltonin in cultured FaDu cell cells. To evaluate the effect of deltonin on cell viability of human hypopharyngeal cancer cell line $\mathrm{FaDu}$, we initially treated $\mathrm{FaDu}$ cells with various doses of deltonin $(0.5$ to $5 \mu \mathrm{M})$ for different time ( $24 \mathrm{~h}$ to $72 \mathrm{~h}$ ), respectively. Cell proliferation was measured by MTT assay. Figure 2A demonstrates that deltonin inhibited cellular proliferation in a dose and time dependent manner. With deltonin treatment inhibition rate was $15 \pm 3 \%, 29 \pm 9 \%, 45 \pm 4 \%$ and $63 \pm 5 \%, 12 \pm 2 \%, 30 \pm 9 \%, 46 \pm 3 \%$ and $60 \pm 4 \%, 10 \pm 3 \%, 31 \pm 9 \%, 59 \pm 2 \%$ and $65 \pm 3 \%$ at $0.5,1,2,5 \mathrm{uM}$ for 24,48 and $72 \mathrm{~h}$ respectively. Importantly, similar deltonin concentrations inhibited slightly the growth of normal human epidermal keratinocytes after $72 \mathrm{~h}$, with a inhibition rate $27 \pm 4 \%$ (Figure $2 \mathrm{~B}$ ). This data suggested deltonin selectivity toward HNSCC cells only. Deltonin showed an $\mathrm{IC}_{50}$ (median growth inhibitory concentration value) of $3.43 \mu \mathrm{M}$ after $24 \mathrm{~h}$ of 


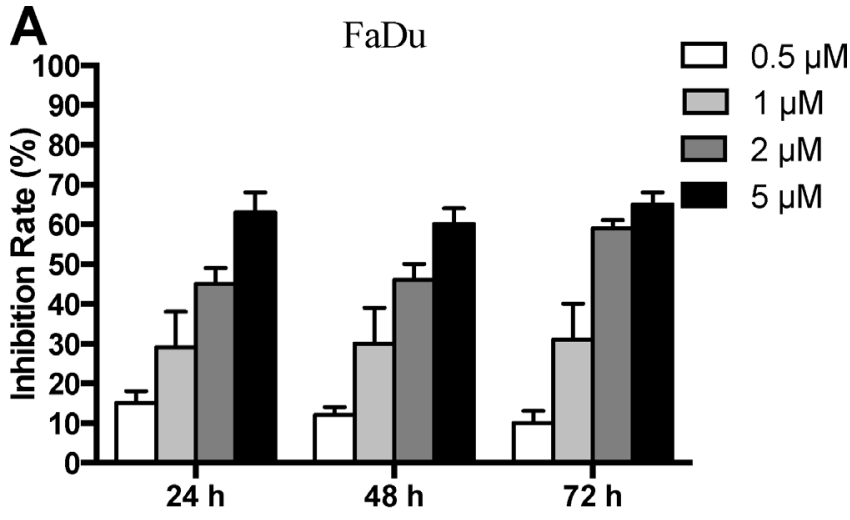

B

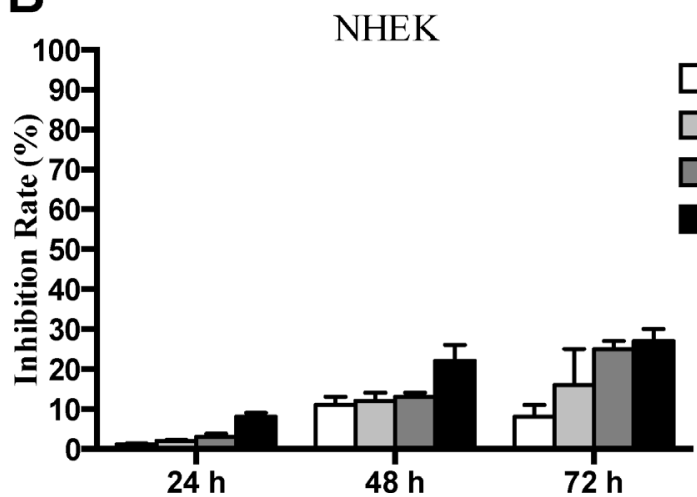

Figure 2. Cytotoxic effects of deltonin on FaDu cells and normal human epidermal keratinocytes (NHEK) cells. Either FaDu Cells (A) or NHEK cells (B) were treated with various concentrations $(0.5 \mu \mathrm{M}, 1 \mu \mathrm{M}, 2 \mu \mathrm{M}$ and $5 \mu \mathrm{M}$ ) of deltonin for 24,48 , or $72 \mathrm{~h}$. Inhibition rate of deltonin was detected by MTT assay. Deltonin apparently inhibited proliferation of hypopharyngeal carcinoma cells in a time- and dose-dependent manner

treatment, implying that deltonin elicits marked cytotoxic effects on FaDu cells.

Effects of deltonin on cell cycle distribution and apoptosis of FaDu cell. Flow cytometric analysis showed that deltonin caused G2/M arrest in FaDu cell but did not affect on the cell cycle of NHEK cells (Figure 3A and 3B). FaDu cells treated with different concentrations $(1,2$ and $5 \mu \mathrm{M}$ respectively) of deltonin for $24 \mathrm{~h}$ predominantly accumulated in the $\mathrm{G}_{2} / \mathrm{M}$ phase of the cell cycle in a concentration-dependent manner, with subsequent accumulation in the $S$ phase of the cell cycle (Figure 3A and Supplementary 1). These results corroborated with the activation of cellular Chk2(Thr68) and Chk1(Ser296 and Ser345), which are known as two critical messengers of the genome integrity checkpoints, without any noticeable change in total Chk2 and Chk1 levels (Figure 3C and F). To further confirm that deltonin induces cell apoptosis, FaDu cells were stained with annexin V-FITC and propidium iodide (PI), and subsequently analyzed by flow cytometry. FaDu cells were treated with different concentrations $(0,1,2$ or $5 \mu \mathrm{M})$ deltonin for $24 \mathrm{~h}$. As indicated in Figure 3D, untreated cells- $4.0 \%$ of cells, were annexin $\mathrm{V}^{+} / \mathrm{PI}^{+}$. After treatment with $5 \mu \mathrm{M}$ deltonin for
$24 \mathrm{~h}$, the corresponding quantity was $60.3 \%$. Adramatic hypodiploid population of $\mathrm{FaDu}$ cells appeared after treatment with deltonin for $24 \mathrm{~h}$ using flow cytometric analysis. The results indicated that deltonin is effective on FaDu cells, which warrants further study of the mechanism of deltonin at cellular and molecular levels.

Effects of deltonin on caspase- 3 signal pathway activation. By western blot analysis, we determined the change of these crucial apoptosis-related proteins in $\mathrm{FaDu}$ cells exposure to deltonin treatment. FaDu cells were treated with deltonin at different concentrations $(0,1,2$ or $5 \mu \mathrm{M})$ for $24 \mathrm{~h}$, and with 5 $\mu \mathrm{M}$ deltonin for $24 \mathrm{~h}, 48 \mathrm{~h}$ or $72 \mathrm{~h}$ to obtain the total proteins for western blot analysis. As shown in Figure 4A and 4B caspase- 9 and -3 were activated by deltonin treatment, the levels of procaspase- 8 , procaspase- 9 and- 3 decreased, and levels of the cleaved caspase- $3,-9$ accumulated in a dose-dependent way of deltonin.

Deltonin on expression of antiapoptotic factor $\mathrm{Bcl}-2$ and proapoptotic protein Bax. We then sought delineate further the mechanisms that underlie the combined effects of deltonin on $\mathrm{FaDu}$ cell apoptosis. We detected the effect of deltonin on expression of a major anti-apoptotic protein Bcl-2.Figure Compared with control group, deltonin treatment reduced the level of $\mathrm{Bcl}-2$ expression significantly $(\mathrm{P}<0.05)$ (Figure $4 \mathrm{~A}$ and $4 \mathrm{~B}$ ). Furthermore, increased levels of proapoptotic protein Bax was also associated with increased deltonin doses (Figure 4A and 4B). .

Deltonin down-regulates p-ERK1/2 expression. The extracellular signal-regulated kinase-1/2 (ERK1/2) pathway is related to tumor growth and survival, and inhibition of ERK1/2 pathway has been shown to induce apoptosis in $\mathrm{FaDu}$ tumor cells [26-28]. As shown in Figure C and 4D, Compared with control group, deltonin reduced the expression of $\mathrm{p}-\mathrm{ERK} 1 / 2$ protein in dose dependency.

Deltonin induced LC3 turnover in FaDu cells. Due to its localization and aggregation on autophagosomes, the lipidated form of LC3 transforming from LC3-I to LC3-II has been considered to be anautophagosomal marker [2930]. To investigate whether deltonin treatment induced processing of LC3-I (18 kDa) to LC3-II (16 kDa), western blot analysis was performed. In Figure 5A, LC3 positive spots were accumulated in deltonin-treated FaDu cells, and the accumulation was more prominent while the dose of deltonin increased. As shown in Figure 5B, LC3-II was accumulated in deltonin-treated $\mathrm{FaDu}$ cells, and the accumulation was more prominent while the dose of deltonin increased. We also found that deltonin upregulated expression of Beclin 1 in a dose-dependent manner.

Deltonin inhibited the Akt-mTOR signaling pathway in FaDu cells. Akt-mTOR signaling is considered atypical negative regulator of autophagy[31]; therefore, we investigated whether phosphorylation of both Akt and mTOR was involved in deltonin-induced autophagy in FaDu cells. As shown in Figure 5C and 5D, deltonin treatment resulted in a noticeable inhibition of both Akt (S473) and mTOR (S2448) 

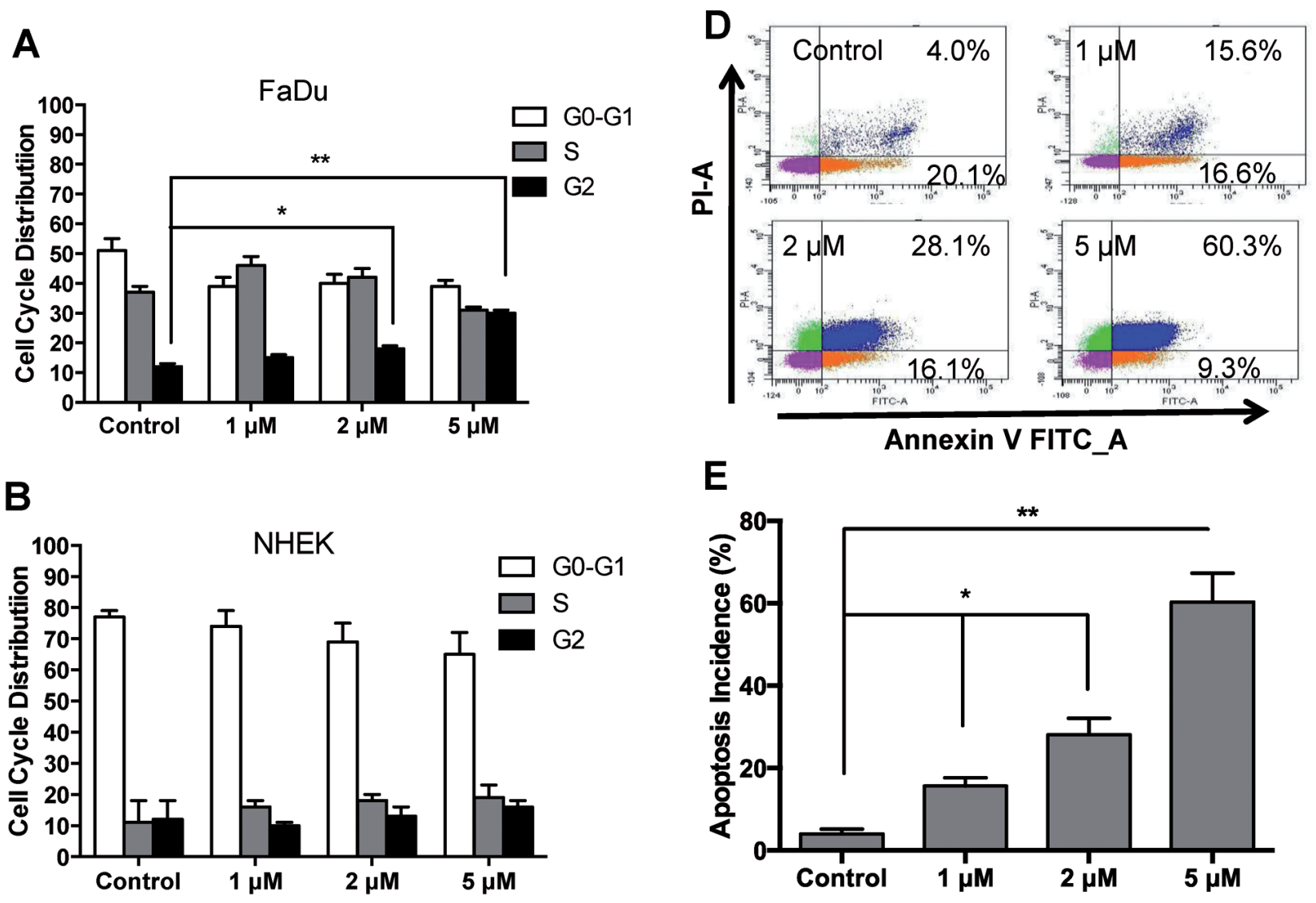

E

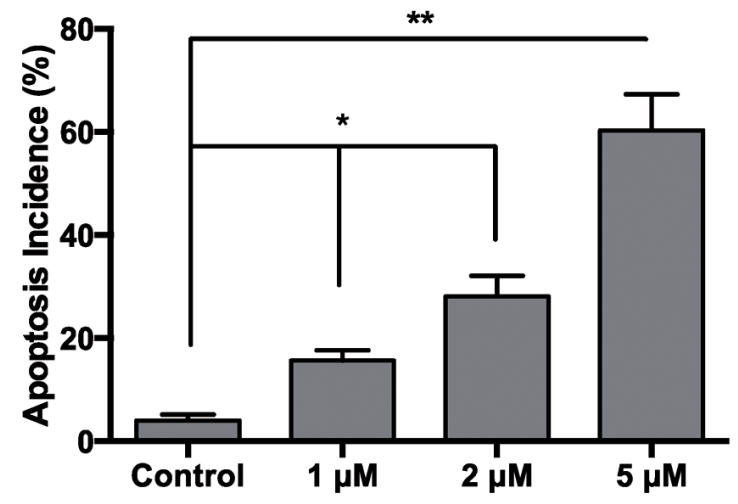

C

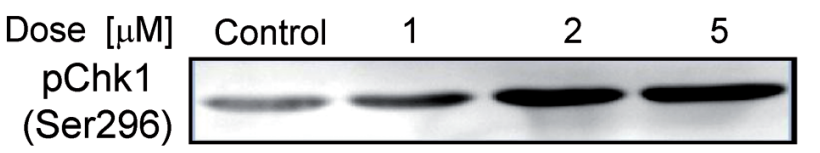

pChk1

(Ser345)

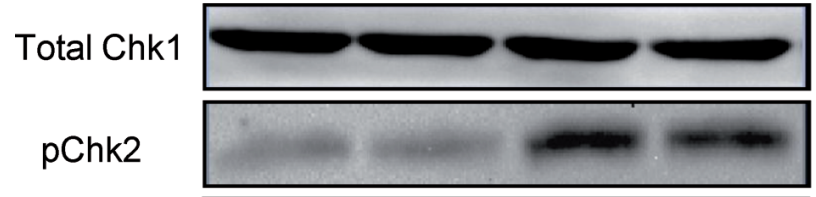

Total Chk2

GAPDH
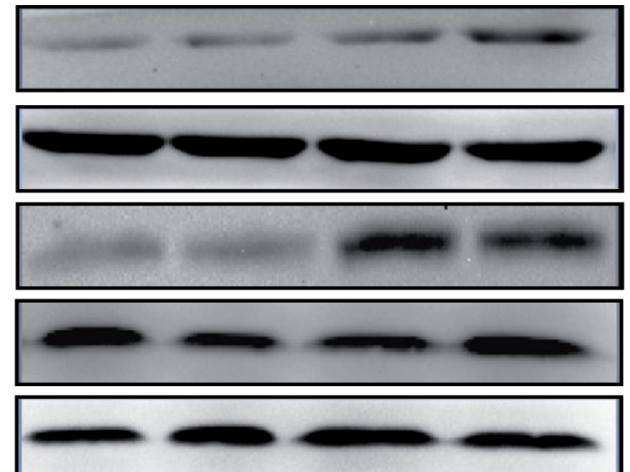

\section{$\mathbf{F}$}

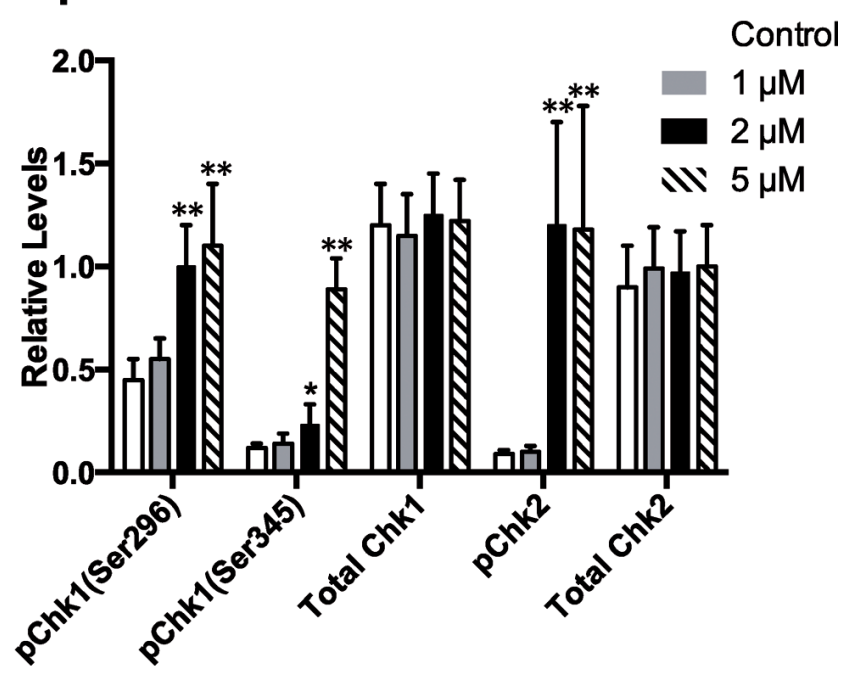

Figure 3. Deltonin promotes G2-Mphase arrest and induces apoptosis in FaDu cells. (A) Deltonin induces G2-M phase arrest in FaDu cells. Quantification of cell cycle distribution analyzed by one-way ANOVA followed by post hoc tests. (B) Effects of Deltonin cell cycle distribution of NHEK cells. (C) Effect of Deltonin on the expression of checkpoint kinase Chk1/Chk2. (D) Assessment of apoptosis in deltonin-treated FaDu cells. After $24 \mathrm{~h}$ of deltonin treatment, induction of apoptosis was determined by flow cytometric analysis of Annexin V-FITC and propidium iodide staining. Cells in the lower right quadrant indicate Annexin ${ }^{+}$early apoptotic cells; cells in the upper right quadrant indicate Annexin ${ }^{+} /$ $\mathrm{PI}^{+}$late apoptotic cells. (E) Quatification of apoptosis in deltonin-treated FaDu cells analyzed by one-way ANOVA followed by post hoc tests. Each bar is representative of mean \pm S.E. of three samples for each treatment. ${ }^{\star} P<0.05,{ }^{*} P<0.01$ vs. control group. (F) A representative result of (C), the relative levels of expression for these proteins were evaluated by densitometry and assessed using Mann-Whitney U-test for nonparametric data. 
phosphorylation in FaDu cells. Meanwhile, deltonin-mediated dephosphorylation of Akt and mTOR was more pronounced with the dose of deltonin increased.

Inhibition of autophagy enhanced deltonin-induced apoptosis in FaDu cells. To explore the biological effect of autophagy in deltonin-mediated apoptotic cell death, a wellknown autophagy inhibitor chloroquine was utilized to disrupt and prevent completion of autophagy. In this round, cells were treated with deltonin, chloroquine alone or in combination. Our study showed that chloroquine enhanced deltonin-in-
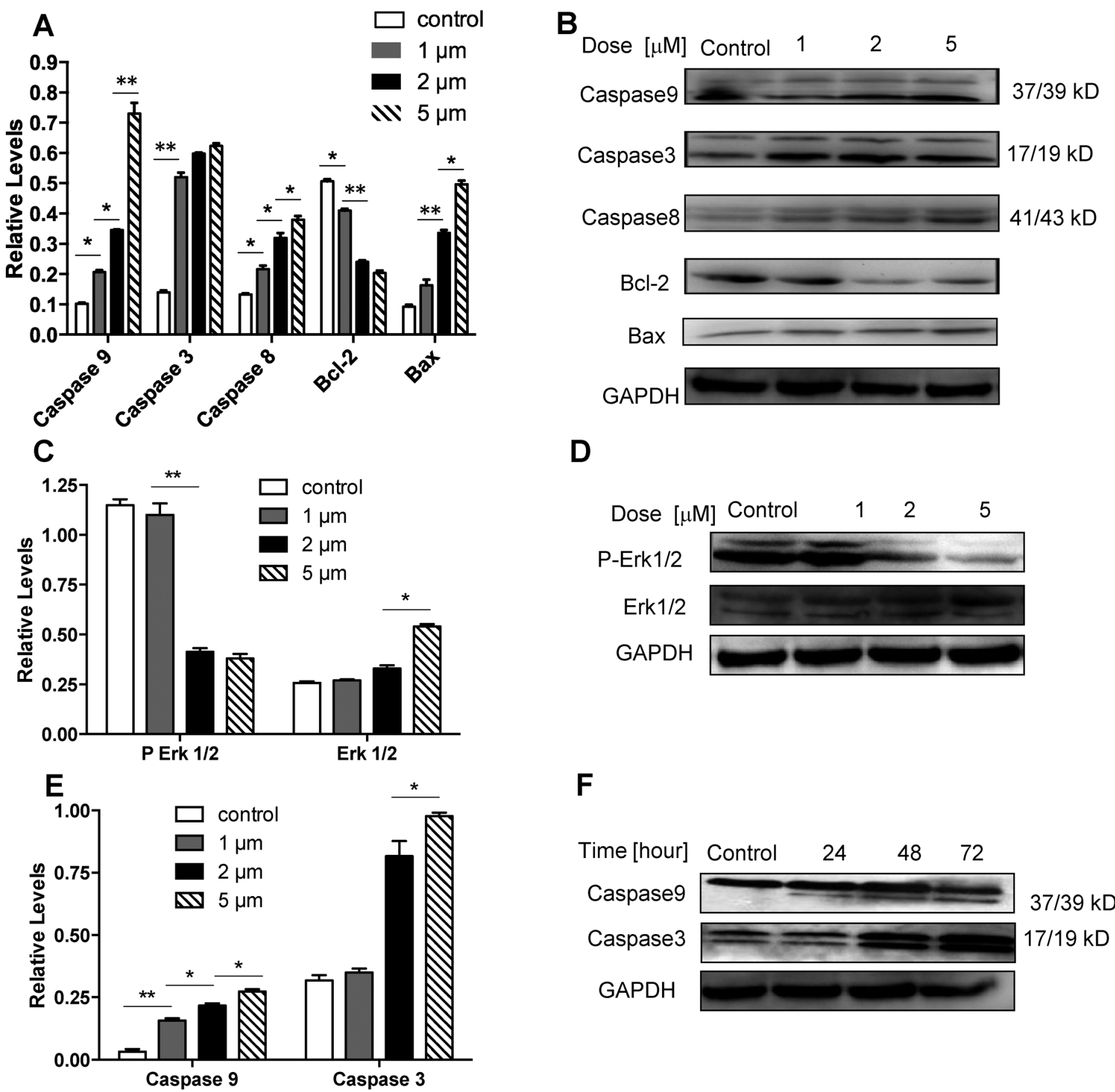

Figure 4. Deltonin induced cell apoptosis in FaDu cells through western blot analysis. Quantitative analysis was performed by densitometric scanning. Bars represent the mean \pm S.E. of 3 different experiments. ${ }^{*} P<0.05 ;^{* *} P<0.01$ vs. control group. (A) Deltonin activated caspase- 3 signal pathway, reduced expression of antiapoptotic factor Bcl-2 and up-regulated expression of proapoptotic protein Bax. GAPDH was used as a loading control. (C) Deltonin resulted in a significant activation (phosphorylation) ofERK1/2. GAPDH was used as a loading control. (E) Expressions of caspase-9 and caspase-3 increased gradually in a time-dependent manner after treatment with deltonin. GAPDH was used as a loading control. (B), (D), (F) A representative result of $(A),(C)$ and (E) respectively. The relative levels of expression for these proteins were evaluated by densitometry. Non-parametric Mann-Whitney $\mathrm{U}$-test was used to compare the data in $\mathrm{A}, \mathrm{C}$ and $\mathrm{E}$. 
duced suppression of FaDu cells growth significantly $(\mathrm{P}<0.01)$ (Figure 6A). In line with this observation, deltonin-induced apoptotic cell death was augmented in the presence of chloroquine, which was demonstrated by TUNEL assays to detect DNA fragmentation (Figure 6B and 6C).
Deltonin's in vivo anti-tumor effects in a FaDu xenograft model. Finally, we tested the in vivo anti-tumor effect of deltonin in a FaDu xenograft model as described in material and methods. The FaDu xenograft mice group that received indicated i.p. injection of deltonin treatment showed a great

A

DMSO

TAM

$1 \mu \mathrm{M}$

$2 \mu \mathrm{M}$

$5 \mu \mathrm{M}$

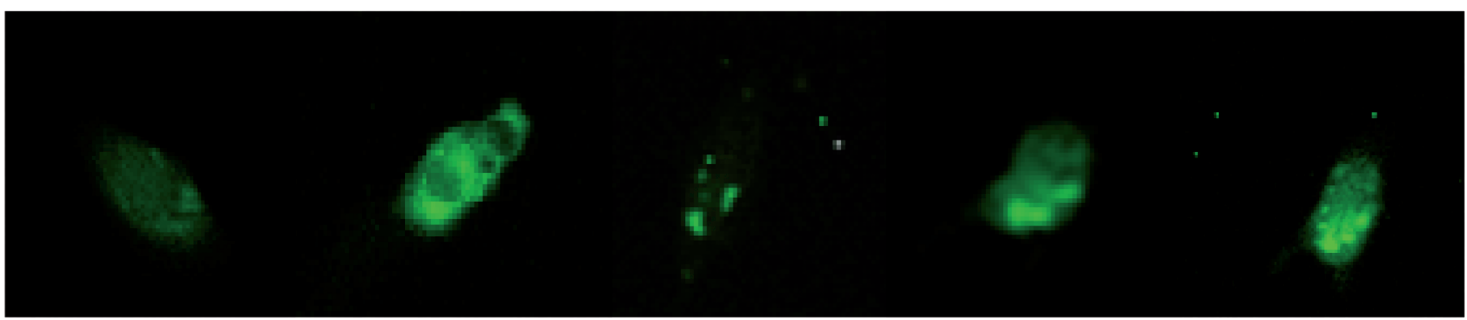

B
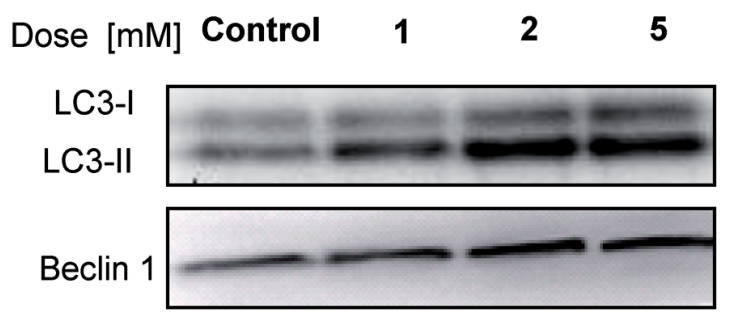

GAPDH

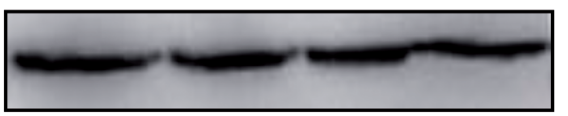

C

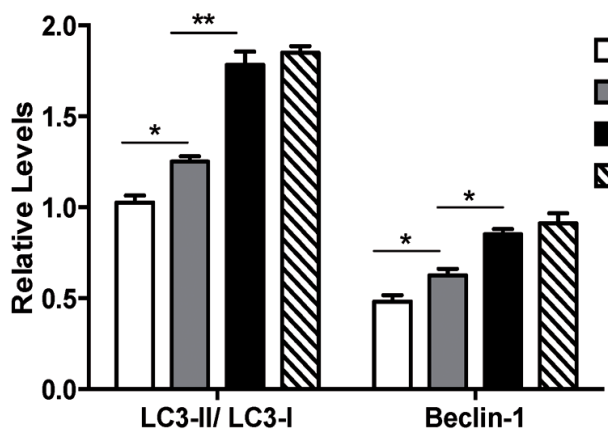

D

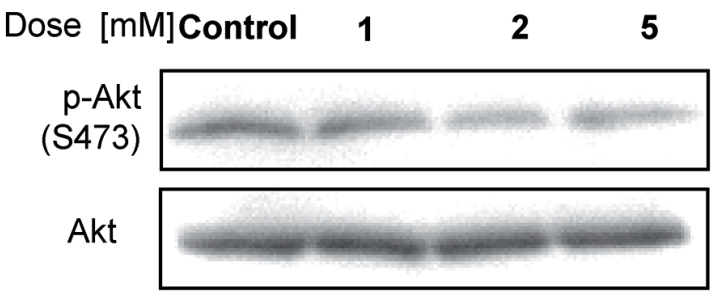

p-mTOR

(S2448)
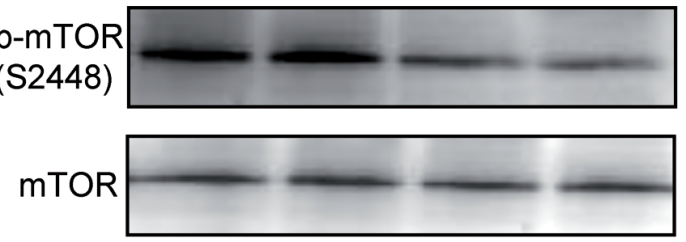

GAPDH
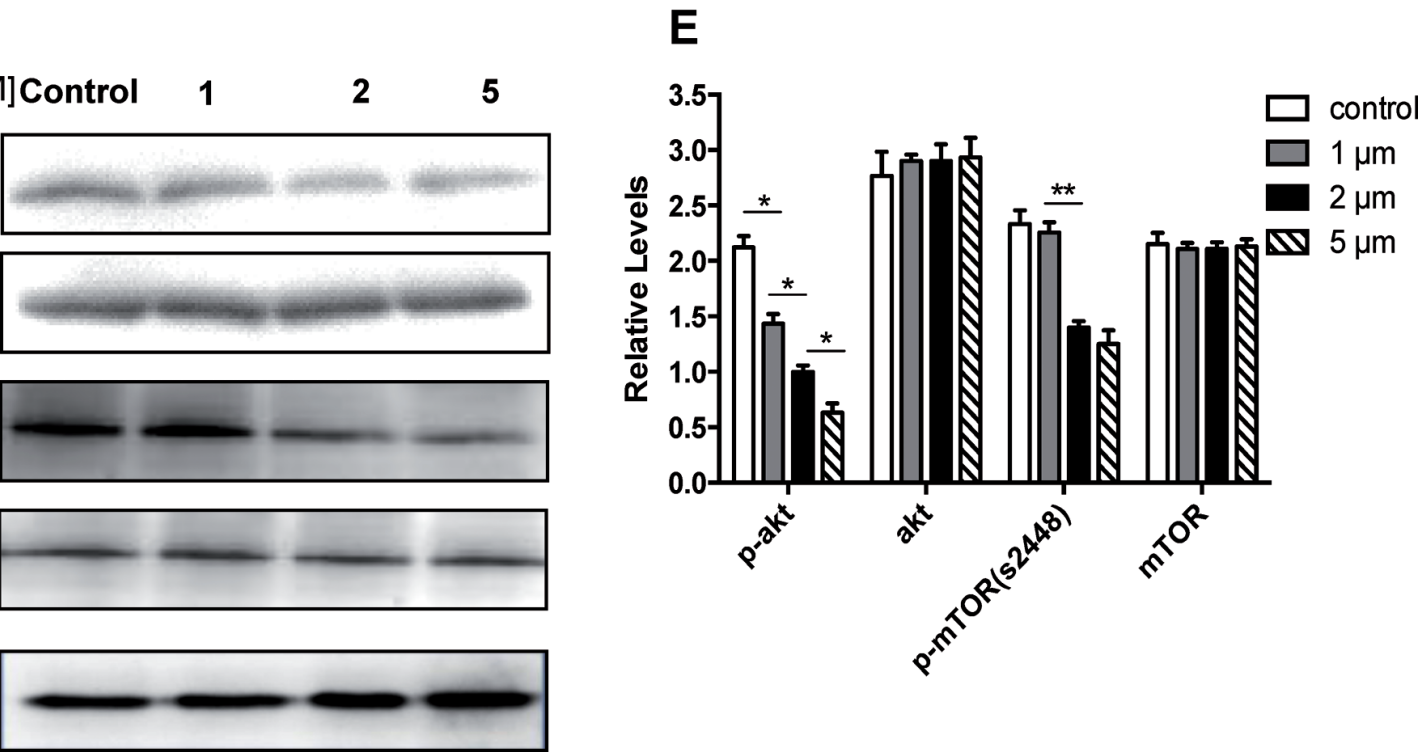

Figure 5. Deltonin induced LC3 turnover and activated autophagy-related genes in gastric cancer cells. (A) FaDu cells were transfected with pEGFP-LC3 plasmid and treated with DMSO $(<0.1 \%), 5 \mu \mathrm{M}$ tamoxifen (positive control) or indicated concentrations of deltonin for $48 \mathrm{~h}$. GFP-LC3 positive cells were defined as that cells have five or more GFP-LC3 punctate dots. The percentage of GFP-LC3 positive cells with GFP-LC3 dots and the average number of GFP-LC3 dots per cell were assessed from 100 random fields. (B) Immunoblot analysis of LC3 and Beclin 1 expression from lysates of FaDu cells treated with various concentrations of deltonin for 48h. $\beta$-actin was used as a loading control. (D) Immunoblot analysis of phosphor-Akt (S473), total Akt, phosphor-mTOR (S2448) and total mTOR from lysates of FaDu cells treated with various concentrations of deltonin for $48 \mathrm{~h}$. $\beta$-actin was used as a loading control. (C), (E) A representative result of (B), (D) respectively, the relative levels of expression for these proteins were evaluated by densitometry. Non-parametric Mann-Whitney U-test was used to compare the data in $\mathrm{C}$ and $\mathrm{E}$. All data were representative of three independent experiments. Values are means \pm S.E. ${ }^{*} P<0.05 ;{ }^{* *} P<0.01$ vs. control group. 
A
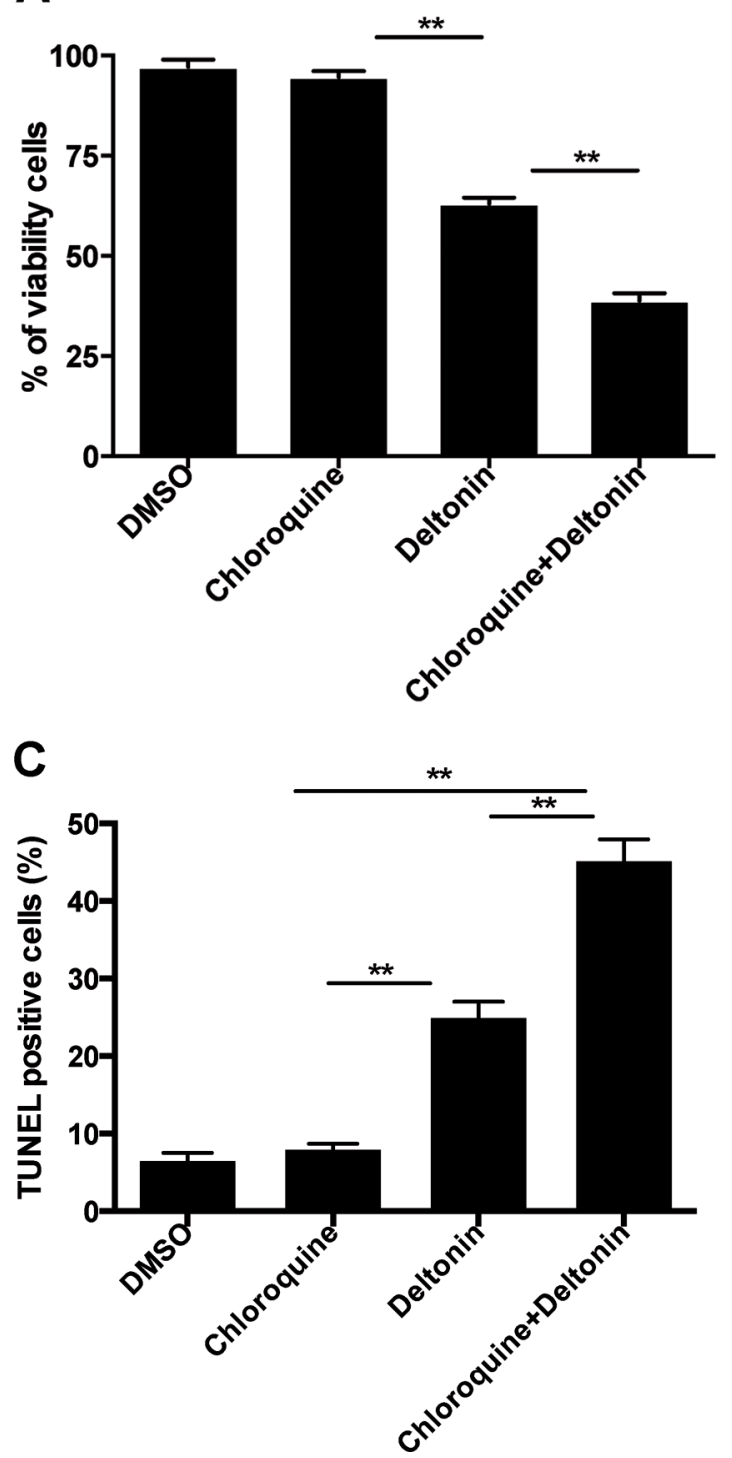

inhibition in tumor growth, which is demonstrated by reduced tumor size (Figure 7A) and improved mice survival and (Figure 7B), indicating a significant anti-tumor ability by deltonin in vivo. In deltonin-treated groups, 40 and 80 $\mathrm{mg} / \mathrm{kg}$ led to reductions in tumor growth of $27.8 \%$ ( $\mathrm{P}<$ $0.05)$ and $44.64 \%(\mathrm{P}<0.01)$ respectively, compared with the vehicle control (Figure 7A). There is an increase in survival in the deltonin-treated groups. At the terminus of the study, compared with the control, the $80 \mathrm{mg} / \mathrm{kg}$ group and $40 \mathrm{mg} /$ $\mathrm{kg}$ group resulted in a 50-day survival rate of $20 \%$ and $15 \%$, respectively (Figure $7 \mathrm{~B})(\mathrm{P}<0.05)$. In addition, there are no significant differences in weight among the groups, indicating lack of toxicity-dependent weight loss in tumor-bearing mice treated with deltonin (Figure 7C). We also observed deltonin caused significant tumor cell apoptosis in Fadu tumor-bearing
B
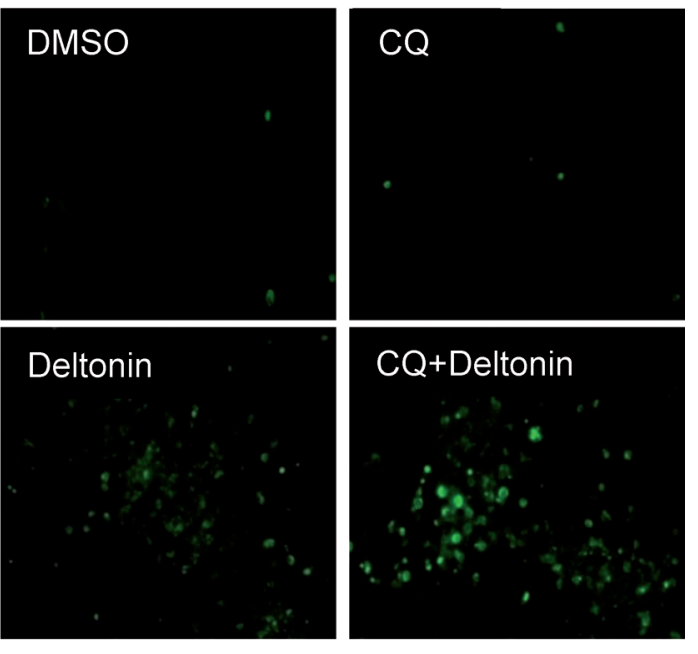

Figure 6. Inhibition of autophagy by chloroquine administration enhanced deltonin-induced apoptosis in FaDu cells. (A) Cell viability was assessed by MTT assay in FaDu cells treated with DMSO $(<0.1 \%)$ and deltonin $(2$ $\mu \mathrm{M}$ ) in the absence or presence of $20 \mu \mathrm{M}$ chloroquine for $48 \mathrm{~h}$ by one-way ANOVA followed by post hoc tests. (B) Apoptotic ratio was assessed by TUNEL assay in FaDu cells treated with DMSO $(<0.1 \%)$ and deltonin $(2$ $\mu \mathrm{M}$ ) in the absence or presence of $20 \mu \mathrm{M}$ chloroquine for $48 \mathrm{~h}$. (C) A representative result of $(B)$. Data represent the mean number of TUNEL-positive cells, were analyzed by one-way ANOVA followed by post hoc tests. All data were representative of three independent experiments. Bars: $\mathrm{SE} .{ }^{*} \boldsymbol{P}<0.05$; ${ }^{* *} P<0.01$ vs. control group.

mice. TUNEL assay was performed to measure cell apoptosis in tumor tissue. Deltonin-treated tumor tissue showed significantly increased number of positive-cells than the control groups (Figure 7D).

To examine the toxicity of deltonin, mice were sacrificed 8 weeks after consecutively oral administration of $80 \mathrm{mg} / \mathrm{kg}$ deltonin. Then main organs including heart, liver, spleen, lung and kidney were taken for histological examination by H\&E staining. As shown in Figure 8, we found no significant change of histopathology in deltonin treated group.

\section{Discussion}

In the present study, we found that deltonin exhibited cytotoxic effect against a hypopharyngeal squamous cell $\mathrm{FaDu}$ both 

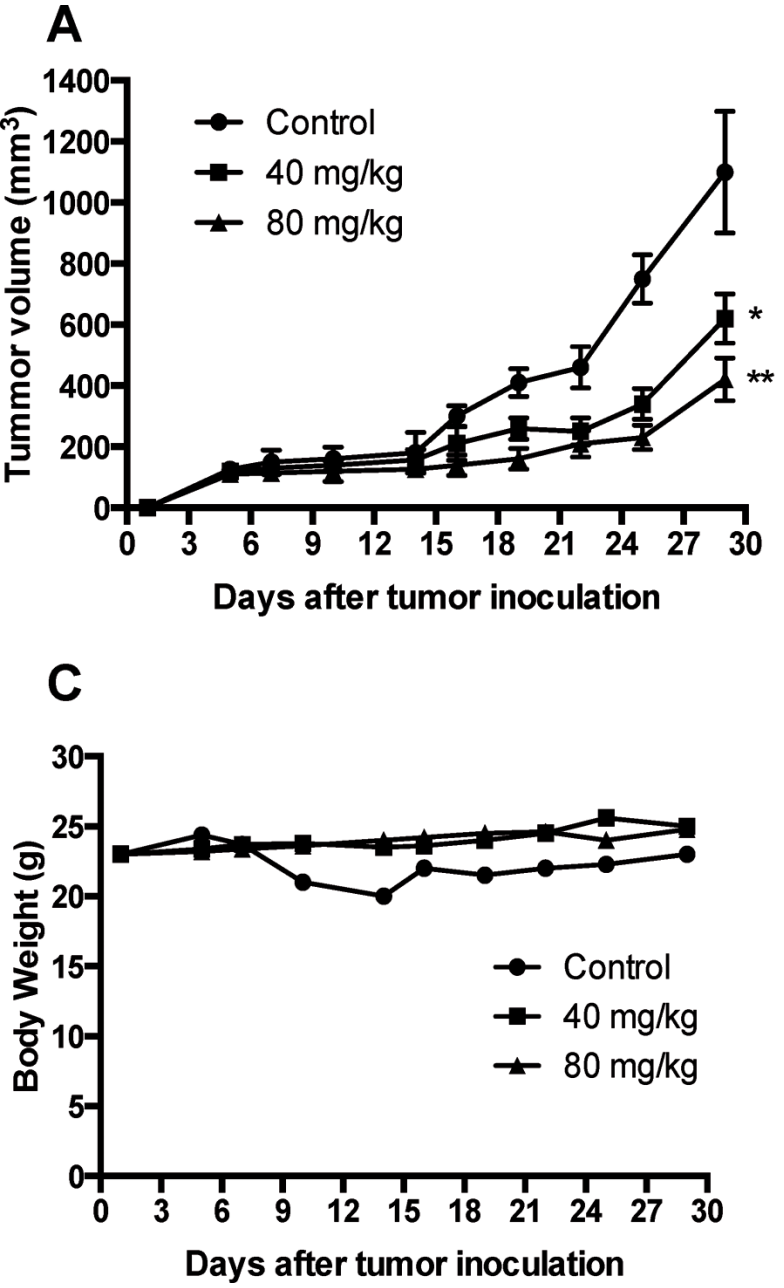

B

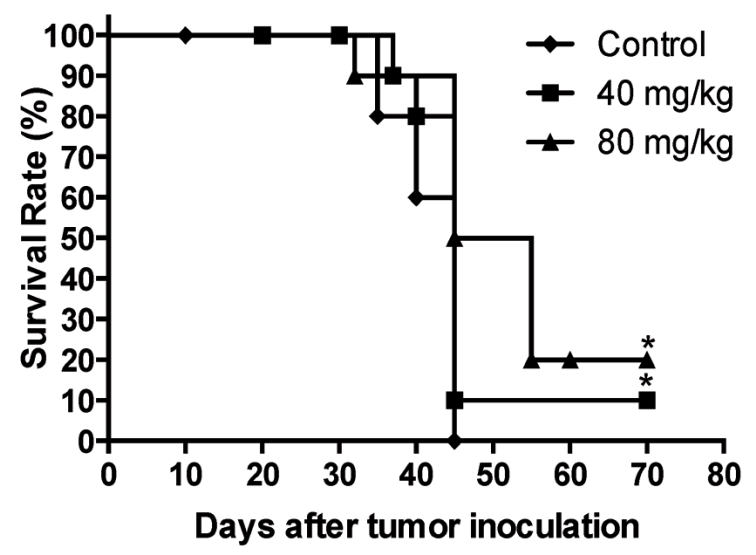

D

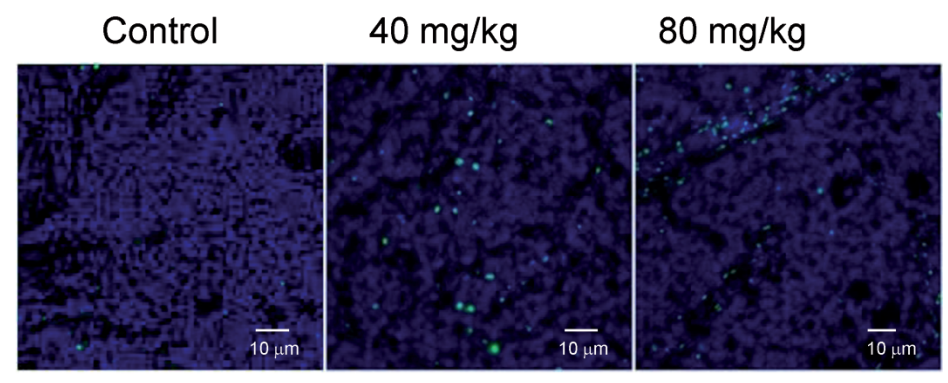

Figure 7. Deltonin inhibits FaDu derived-tumor growth and prolongs the survival of the hypopharyngeal carcinoma tumor-bearing mice. (A) Suppression of tumor growth in deltonin-treated groups, 40 and $80 \mathrm{mg} / \mathrm{kg}$ led to reductions in tumor growth of $27.8 \%$ and $44.64 \%$ respectively, compared with the vehicle control. Bars: SE. ${ }^{\star}<0.05,{ }^{*}<0.01$ vs. control group. (B) An increase in survival in the deltonin-treated groups, compared with the vehicle control $(\mathrm{P}<0.05)$. (C) Lack of toxicity-dependent weight loss in tumor-bearing mice treated with deltonin. There are no significant differences in weight among the groups. Values are means \pm S.E.P $<0.01$. At the terminus of the study, compared with the control, the $80 \mathrm{mg} / \mathrm{kg}$ group and $40 \mathrm{mg} / \mathrm{kg}$ group resulted in a 50-day survival rate of $20 \%$ and $15 \%$, respectively. (D) Representative TUNEL data presented as the apoptotic cells of treated tumor tissue, which showed that deltonin treated induced a significant enhancement of apoptotic cells in contrast to control therapies $($ original magnification $200 \times)$.

in vitro and in vivo. In vitro, deltonin had a dose-dependent effect on cytotoxicity of FaDu cells by reducing viability in relation to control (Figure 2). By using flow cytometry analysis, deltonin interfered in cell cycle arrest and showed an increased proportion of hypodiploid DNA. Western blot analysis showed that deltonin induced apoptosis via ERK1/2 and Caspase kinase pathways. What's more, to our surprise, we observed an induction of protective autophagy in $\mathrm{FaDu}$ cells while inducing apoptosis by deltonin. In vivo, deltonin treatment displayed anti-tumor activities in murine model of hypopharyngeal carcinoma xenografts.

Cell cycle control has been proven to be an important strategy in cancer therapy, while abnormalities of cell cycle regulators have been associated with many carcinogenic processes. There was a prominent increase in the G2/M DNA after deltonin treatment (Figure 3A), suggesting that deltonin could prevent FaDu cells from entering mitosis, and inhibit carcinoma cell growth by this pathway in a concentrationdependent manner. This is line with a Chk1/2 activation in FaDu cells exposured to deltonin (Figure 3C and F). In general, activated by Ataxia telangiectasia mutated protein (ATM) and ataxia telangiectasia and Rad3-related protein (ATR), Chk1 and Chk2 play a pivotal role in controlling progression of cells through different phase of cell cycle, which deter cells to enter new phase without the successful completion of the earlier phase $[32,33]$. In the G2/M checkpoint, the activated CHK1 or CHK2 phosphorylates and inhibits the cell division cycle 25 (Cdc25) phosphatase activity [34,35]. Our result probably of- 

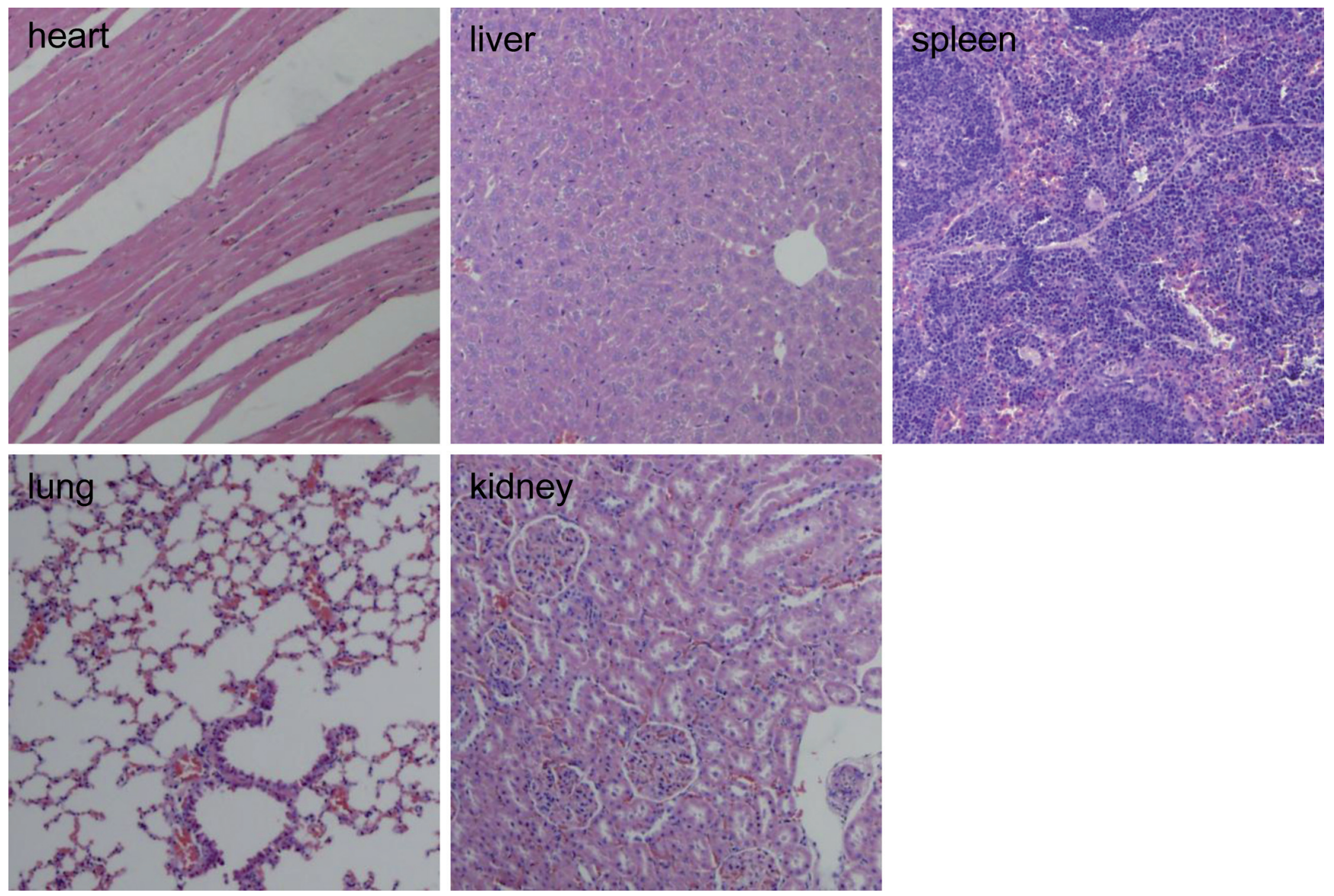

Figure 8. Deltonin toxicity in mice. Deltonin $(80 \mathrm{mg} / \mathrm{kg}$ daily) was administered for 8 weeks. Representative sections of heart, liver, spleen, lung, and kidney were stained with hematoxylin and eosin (original magnification, 100x).

fered a reasonable explanation in an earlier report on colorectal cancer, deltonin was reported to exhibit a promoting dramatic G2-M phase arrest in CT26 cell [24].

Inducing apoptosis is an important strategy to overcome cancer [36,37,38]. Previous studies proved that activations of caspase- 9 and caspase- 3 lead to apoptosis in FaDu cells $[39,40]$. Here, deltonin treatment altered expression levels of caspase- 3 , caspase- 8 and caspase- 9 in concentration- and time-dependent manners and also increased the expression of Bax in concentration dependent manner (Figure 4A and $4 \mathrm{~B})$. These findings suggested that deltonin treatment mediated cross-talk between the intrinsic and extrinsic apoptotic pathways by altering expression levels of several regulators of these pathways, such as caspase-9, caspase-3, Bax. ERK1/2 pathway is known to dictate cell fate during DNA damage, mitogenic stimuli, and survival [41]. ERK1/2 phosphorylates caspase- 9 at Thr125 then inhibits caspase- 9 processing and caspase- 3 activation [42]. Inhibition of ERK1/2 phosphorylation is proved to blockade CXCL12-induced FaDu migration and chemoinvasion, suggesting that activation of ERK1/2 is an important step in the signal that leads to increased migration and chemoinvasion of HNSCC [43]. A very recent research showed that ERK1/2 MAPK mediated FaDu cell death via a caspase-independent mechanism [44]. We found that the level of $\mathrm{p}$-ERK1/2 protein was reduced in $\mathrm{FaDu}$ cells treated with deltonin (Figure 4C and 4D), consistent with the previous study of Kian Ang et al., that the decreased activity of p-ERK1/2 in hypopharyngeal cancer cells was accompanied by cell death in HNSCC [45]. The reduction of phosphorylated ERK1/2 activation was accompanied with the activation of caspase- 9 and -3 (Figure 4E and 4F). These results suggested that deltonin may suppress hypopharyngeal squamous cell carcinoma through targets including the supporting cell-survival function of ERK and activating apoptotic signals. Further study should be done to elucidate the role of p-ERK $1 / 2$ in deltonin induced apoptosis.

Of interest, we discovered autophagy enhancement by deltonin, in addition to apoptosis incitation (Figure 5). Monitoring conversion from LC3-I to LC3-II is widely used as a marker for autophagosome determination. Protein Atg6 (also called beclin 1) is considered to have a central role during the initiation of autophagosome formation. By interacting 
with several cofactors (Atg14L, UVRAG, Bif-1, Rubicon, Ambra1, HMGB1, nPIST, VMP1, SLAM, IP3R, PINK and survivin), Beclin 1 regulate lipid kinase Vps-34 protein and promote formation of Beclin 1-Vps34-Vps15 core complexes, thereby inducing autophagy. As one of the classic pathway that regulates autophagy, mTOR activity inhibits autophagy. Akt-mTOR signaling pathway is the major negative signaling pathway against autophagy [31]. In addition, increasing levels of Akt activation correlates with an increase in the malignant potential of HNSCC [46]. Akt activation occurs by phosphorylation at T308 and S473 residues and has been validated as a critical step in the initiation and maintenance of metastatic tumors [47]. Chemical interaction of Akt is reported to cause apoptosis, and inhibit chemotaxis and migration FaDu cells in vitro [48]. When treated with deltonin, downregulated levels both dephosphorylated Akt at Ser473 and p-mTOR at s2448 were found in $\mathrm{FaDu}$ cells (Figure 5C and 5D), suggesting a profound effect of deltonin on Akt/mTOR signaling network in $\mathrm{FaDu}$ cells.

Although the relationship between apoptosis and autophagy is still unclear, there are crucial proteins that are relevant to both processes, implying some degree of crosstalk: $\mathrm{Bcl} 2$ and $\mathrm{Bcl}-\mathrm{XL}$ are anti- apoptotic as well as being blockers of autophagy. Pattingre et al. reported that the anti-apoptotic protein, Bcl-2, interacts with the evolutionarily conserved autophagy protein, such as Beclin-1 [49]. Chloroquine is a lysosomotropic agent that has been suggested to inhibit autophagy by perturbing lysosomal function. Blocking autophagy by utilizing of chloroquine increase the susceptibility to FaDu cell to pro-apoptotic insults (Figure 6), suggesting that delotonin-induced autophagy plays a protective role in $\mathrm{FaDu}$ cells. Certain anticancer agents such as polyoxomolybdates-, platonin- or phenethyl isothiocyanate could induce autophagy to enhance chemotherapeutic efficacy $[50,51,52]$, while others, i.e., arginine deiminase, suberoylanilide hydroxamic acid or timosaponin A-III mediated protective autophagy that antagonized apoptotic cell death $[53,54,55]$.

In a very recently pharmacokinetic study in rats, deltonin was reported as a nature agent characterized by high apparent clearance $(\mathrm{CL} / \mathrm{F})$ and low bioavailability after oral administration [57]. Hence, in current study, we determined in vivo anti-tumor ability of deltonin by intraperitoneally administration in order to get a possible better bioavailability (Figure 7). Either dose of 80 or $40 \mathrm{mg} / \mathrm{kg}$.day of deltonin decreased tumor sizes by a dose-dependent manner after a 3-week treatment period in a mice model. Deltonin also prolonged the survival of the hypopharyngeal carcinoma tumor-bearing mice. To examine the toxicity of deltonin, mice were sacrificed 8 weeks after consecutively oral administration of $80 \mathrm{mg} / \mathrm{kg}$ deltonin (higher dose). Then histopathological analysis of several organs and serum biochemical parameters were analyzed. As shown in Figure 8, we found no significant difference of histopathology in deltonin group.

Our current study revealed a hitherto undescribed cellular response showing that deltonin induced autophagy antagonizing apoptotic cell death in $\mathrm{FaDu}$ cancer cells.In terms of the molecular machineries and signaling cascades, we offered evidence that involvement of Akt-mTOR signaling in deltonin-induced autophagic progression. This work will not only enrich our understanding of deltonin in cancer treatment, but also be helpful for the development of the whole family of saponins in disease treatment and structure modification.

Supplementary information is available in the online version of the paper.

Acknowledgments: We thank Dr. Xiao-Hua Wu from the Institute for Nanobiomedical Technology and Membrane Biology of Sichuan University, for kindly providing deltonin used in the present research. This work was supported by National Natural Science Foundation of China (No. 8100093).

\section{References}

[1] REZENDE TM, DE SOUZA FREIRE M, FRANCO OL. Head and neck cancer: proteomic advances and biomarker achievements. Cancer 2010; 116: 4914-4925. http://dx.doi. org/10.1002/cncr.25245

[2] ARGIRIS A, KARAMOUZIS MV, RABEN D, FERRIS RL. Head and neck cancer. Lancet 2008; 371: 1695-1709. http:// dx.doi.org/10.1016/S0140-6736(08)60728-X

[3] SCHAAIJ-VISSER TB, BRAKENHOFF RH, LEEMANS CR, HECK AJ, SLIJPER M. Protein biomarker discovery for head and neck cancer. J Proteomics 2010; 73: 1790-1803. http:// dx.doi.org/10.1016/j.jprot.2010.01.013

[4] MENDENHALL WM, WERNING JW, HINERMAN RW, AMDUR RJ, VILLARET DB. Management of T1-T2 glottic carcinomas. Cancer 2004; 100: 1786-1792. http://dx.doi. org/10.1002/cncr.20181

[5] NIU YP, LI LD, WU LM. Beta-aescin: A potent natural inhibitor of proliferation and inducer of apoptosis in human chronic myeloid leukemia K562 cells in vitro. Leuk Lymphoma 2008; 49: 1384-1391. http://dx.doi. org/10.1080/10428190802090151

[6] ZHU J, GUO X, FU S, ZHANG X, LIANG X. Characterization of steroidal saponins in crude extracts from Dioscorea zingiberensis C. H. Wright by ultra-performance liquid chromatography/electrospray ionization quadrupole time-of-flight tandem mass spectrometry. J Pharm Biomed Anal 2010; 53: 462-474. http://dx.doi.org/10.1016/j.jpba.2010.05.019

[7] LIU L, DONG YS, QI SS, WANG H, XIU ZL. Biotransformation of steriodal saponins in Dioscorea zingiberensis C. H. Wright to diosgenin by Trichoderma harzianum. Appl Microbiol Biotechnol 2010; 85: 933-940. http://dx.doi.org/10.1007/ s00253-009-2098-1

[8] LI H, HUANG W, WEN Y, GONG G, ZHAO Q, YU G. Qualitative and quantitative analysis of microbial transformation of steroidal saponins in dioscorea zingiberensis. Fitoterapia 2010; 81: 1147-1156. http://dx.doi.org/10.1016/j. fitote.2010.07.016 
[9] QI SS, DONG YS, ZHAO YK, XIU ZL. Qualitative and Quantitative Analysis of microbial transformation of steroidal saponins in dioscorea zingiberensis. Chromatographia 2009; 69: 865-870. http://dx.doi.org/10.1365/s10337-0090978-2

[10] OHTSUKI T, SATO M, KOYANO T, KOWITHAYAKORN T, KAWAHARA N, GODA Y, et al. Steroidal saponins from Calamus insignis, and their cell growth and cell cycle inhibitory activities. Bioorg Med Chem 2006; 14: 659-665. http:// dx.doi.org/10.1016/i.bmc.2005.08.059

[11] STORY MJ, WAYTE KM. Methods and compositions for inhibiting angiogenesis. Google Patents, 2007.

[12] EISENBERG-LERNER A BS, SIMON H, KIMCHI A. Life and death partners: apoptosis, autophagy and the cross-talk between them. Cell Death Differ 2009; 16: 966-975. http:// dx.doi.org/10.1038/cdd.2009.33

[13] XIE Z, KLIONSKY DJ. Autophagosome formation: core machinery and adaptations. Nat Cell Bio 2007; 9: 1102-1109. http://dx.doi.org/10.1038/ncb1007-1102

[14] GENG J, KLIONSKY DJ. The Atg8 and Atg12 ubiquitin-like conjugation systems in macroautophagy. EMBO reports 2008; 9: 859-864. http://dx.doi.org/10.1038/embor.2008.163

[15] KROEMER G, MARINO G, LEVINE B. Autophagy and the integrated stress response. Mol Cell 2010; 40: 280-293. http:// dx.doi.org/10.1016/j.molcel.2010.09.023

[16] YANG Z, KLIONSKY DJ. Mammalian autophagy: core molecular machinery and signaling regulation. Curr Opin Cell Bio 2010; 22: 124-131. http://dx.doi.org/10.1016/j. ceb.2009.11.014

[17] LUO S, RUBINSZTEIN D. Atg5 and Bcl-2 provide novel insights into the interplay between apoptosis and autophagy. Cell Death Diff 2007; 14: 1247-1250. http://dx.doi.org/10.1038/ sj.cdd. 4402149

[18] FUJITA N, ITOH T, OMORI H, FUKUDA M, NODA T, et al. The Atg16L complex specifies the site of LC3 lipidation for membrane biogenesis in autophagy. Mol Bio Cell 2008; 19: 2092-2100. http://dx.doi.org/10.1091/mbc.E07-12-1257

[19] YOUSEFI S, PEROZZO R, SCHMID I, ZIEMIECKI A, SCHAFFNER T, et al. Calpain-mediated cleavage of Atg5 switches autophagy to apoptosis. Nature Cell Bio 2006; 8: 1124-1132. http://dx.doi.org/10.1038/ncb1482

[20] LEVINE B, SINHA SC, KROEMER G. Bcl-2 family members: dual regulators of apoptosis and autophagy. Autophagy 2008; 4: 600-606. http://dx.doi.org/10.4161/auto.6260

[21] BAI Y, MAO QQ, QIN J, ZHENG XY, WANG YB, et al. Resveratrol induces apoptosis and cell cycle arrest of human T24 bladder cancer cells in vitro and inhibits tumor growth in vivo. Cancer Sci 2010; 101: 488-493. http://dx.doi. org/10.1111/j.1349-7006.2009.01415.x

[22] TU S, WAI-YIN SUN R, LIN MCM, TAO CUI J, ZOU B, et al. Gold (III) porphyrin complexes induce apoptosis and cell cycle arrest and inhibit tumor growth in colon cancer. Cancer 2009; 115: 4459-4469. http://dx.doi.org/10.1002/cncr.24514

[23] WALDRON NN, KAUFMAN DS, OH S, INDE Z, HEXUM MK, et al. Targeting tumor-initiating cancer cells with dCD133KDEL shows impressive tumor reductions in a xenotransplant model of human head and neck cancer.
Mol Cancer Ther 2011; 10: 1829-1838. http://dx.doi. org/10.1158/1535-7163.MCT-11-0206

[24] TONG QY, HE Y, ZHAO QB, QING Y, HUANG W, et al. Cytotoxicity and apoptosis-inducing effect of steroidal saponins from Dioscorea zingiberensis Wright against cancer cells. Steroids 2012; 77: 1219-1227. http://dx.doi.org/10.1016/j. steroids.2012.04.019

[25] BRUZZESE F, DI GENNARO E, AVALLONE A, PEPE S, ARRA C, et al. Synergistic antitumor activity of epidermal growth factor receptor tyrosine kinase inhibitor gefitinib and IFN-alpha in head and neck cancer cells in vitro and in vivo. Cli Cancer Res 2006; 12: 617-625. http://dx.doi.org/10.1158/1078-0432.CCR-05-1671

[26] BALMANNO K, COOK SJ. Tumour cell survival signalling by the ERK1/2 pathway. Cell Death Differ 2008; 16: 368-377. http://dx.doi.org/10.1038/cdd.2008.148

[27] SEILER N, RAUL F. Polyamines and apoptosis. J Cell Mol Med 2005; 9: 623-642. http://dx.doi.org/10.1111/j.1582-4934.2005. tb00493.x

[28] AMORNPHIMOLTHAM P, PATEL V, SODHI A, NIKITAKIS NG, SAUK JJ, et al. Mammalian target of rapamycin, a molecular target in squamous cell carcinomas of the head and neck. Can Res 2005; 65: 9953-9961. http://dx.doi.org/10.1158/00085472.CAN-05-0921

[29] RUBINSZTEIN DC, CUERVO AM, RAVIKUMAR B, SARKAR S, KOROLCHUK VI, et al. In search of an "autophagomometer”. Autophagy 2009; 5: 585-589. http://dx.doi. org/10.4161/auto.5.5.8823

[30] TANIDA I, UENO T, KOMINAMI E. LC3 conjugation system in mammalian autophagy. Int J Bio 2004; 36: 2503-2518.

[31] SHINTANI T, KLIONSKY DJ. Autophagy in health and disease: a double-edged sword. Science 2004; 306: 990-995. http://dx.doi.org/10.1126/science.1099993

[32] MOLINARI M. Cell cycle checkpoints and their inactivation in human cancer. Cell Prolif 2000; 33: 261-274. http://dx.doi. org/10.1046/j.1365-2184.2000.00191.x

[33] BARTEK J, LUKAS J. Chk1 and Chk2 kinases in checkpoint control and cancer. Cancer Cell 2003; 3: 421-429. http:// dx.doi.org/10.1016/S1535-6108(03)00110-7

[34] DECKBAR D, JEGGO PA, LOBRICH M. Understanding the limitations of radiation induced cell cycle checkpoints. Crit Rev Biochem Mol Biol 2011; 46: 271-283. http:// dx.doi.org/10.3109/10409238.2011.575764

[35] ZHAO H, WATKINS JL, PIWNICA-WORMS H. Disruption of the checkpoint kinase $1 /$ cell division cycle $25 \mathrm{~A}$ pathway abrogates ionizing radiation-induced S and G2 checkpoints. Proc Natl Acad Sci USA 2002; 99: 14795-14800. http://dx.doi. org/10.1073/pnas.182557299

[36] MCKNIGHT JJ, GRAY SB, O'KANE HF, JOHNSTON SR, WILLIAMSON KE. Apoptosis and chemotherapy for bladder Cancer. J Urol 2005; 173: 683-690. http://dx.doi. org/10.1097/01.ju.0000143194.79287.a9

[37] RUPNOW BA, KNOX SJ. The role of radiation-induced apoptosis as a determinant of tumor responses to radiation therapy. Apoptosis 1999; 4: 115-143. http://dx.doi. org/10.1023/A:1009675028784

[38] DOWSETT M, ARCHER C, ASSERSOHN L, GREGORY RK, ELLIS PA, et al. Clinical studies of apoptosis and proliferation 
in breast cancer. Endocr Relat Cancer 1999; 6: 25-28. http:// dx.doi.org/10.1677/erc. 0.0060025

[39] LIN ML, LU YC, SU HL, LIN HT, LEE CC, et al. Destabilization of CARP mRNAs by aloe-emodin contributes to caspase-8-mediated p53-independent apoptosis of human carcinoma cells. J Cellular Biochem 2011; 112: 1176-1191. http://dx.doi.org/10.1002/jcb.23031

[40] SHROTRIYA S, DEEP G, GU M, KAUR M, JAIN AK, et al. Generation of reactive oxygen species by grape seed extract causes irreparable DNA damage leading to G2/M arrest and apoptosis selectively in head and neck squamous cell carcinoma cells. Carcinogenesis 2012; 33: 848-858. http://dx.doi. org/10.1093/carcin/bgs019

[41] ZHOU Y, WANG Q, EVERS BM, CHUNG DH. Signal Transduction Pathways Involved in Oxidative Stress-Induced Intestinal Epithelial Cell Apoptosis. Pediatr Res 2005; 58: 11921197. http://dx.doi.org/10.1203/01.pdr.0000185133.65966.4e

[42] ALLAN LA, MORRICE N, BRADY S, MAGEE G, PATHAK $S$, et al. Inhibition of caspase- 9 through phosphorylation at Thr 125 by ERK MAPK. Nat Cell Biol 2003; 5: 647-654. http:// dx.doi.org/10.1038/ncb1005

[43] TAN CT, CHU CY, LU YC, CHANG CC, LIN BR, et al. CXCL12/CXCR4 promotes laryngeal and hypopharyngeal squamous cell carcinoma metastasis through MMP-13-dependent invasion via the ERK1/2/AP-1 pathway. Carcinogenesis 2008; 29: 1519-1527. http://dx.doi. org/10.1093/carcin/bgn108

[44] YANG YJ, LEE NK, LEE NY, LEE JW, PARK SJ. Cell death mediated by Vibrio parahaemolyticus type III secretion system 1 is dependent on ERK1/2 MAPK, but independent of caspases. J Microbiol and Biotechnol 2011; 21: 903-913. http://dx.doi. org/10.4014/jmb.1104.04044

[45] ANG KK, BERKEY BA, TU X, ZHANG HZ, KATZ R, et al. Impact of epidermal growth factor receptor expression on survival and pattern of relapse in patients with advanced head and neck carcinoma. Cancer Res 2002; 62: 7350-7356.

[46] NAKAYAMA H, IKEBE T, BEPPU M, SHIRASUNA K. High expression levels of nuclear factor kappaB, IkappaB kinase alpha and Akt kinase in squamous cell carcinoma of the oral cavity. Cancer 2001; 92: 3037-3044. http:// dx.doi.org/10.1002/1097-0142(20011215)92:12<3037::AIDCNCR10171>3.0.CO;2-\#

[47] CARNERO A, BLANCO-APARICIO C, RENNER O, LINK W, LEAL JF. The PTEN/PI3K/AKT signalling pathway in cancer, therapeutic implications. Curr Cancer Drug targets 2008; 8: 187-198. http://dx.doi.org/10.2174/156800908784293659

[48] KNOWLES JA, GOLDEN B, YAN L, CARROLL WR, HELMAN EE, et al. Disruption of the AKT pathway inhibits metastasis in an orthotopic model of head and neck squamous cell carcinoma. The Laryngoscope 2011; 121: 2359-2365. http://dx.doi.org/10.1002/lary.22180

[49] PATTINGRE S, TASSA A, QU X, GARUTI R, LIANG XH, et al. Bcl-2 Antiapoptotic Proteins Inhibit Beclin 1-Dependent Autophagy. Cell 2005; 122: 927-939. http://dx.doi. org/10.1016/j.cell.2005.07.002

[50] OGATA A, YANAGIE H, ISHIKAWA E, MORISHITA Y, MITSUI S, et al. Antitumour effect of polyoxomolybdates: induction of apoptotic cell death and autophagy in in vitro and in vivo models. Br J Cancer 2007; 98: 399-409. http:// dx.doi.org/10.1038/sj.bjc.6604133

[51] CHEN YJ, HUANG WP, YANG YC, LIN CP, CHEN SH, et al. Platonin induces autophagy-associated cell death in human leukemia cells. Autophagy 2009; 5: 173-183. http://dx.doi. org/10.4161/auto.5.2.7360

[52] BOMMAREDDY A, HAHM E-R, XIAO D, POWOLNY AA, FISHER AL,et al. Atg5 Regulates Phenethyl IsothiocyanateInduced Autophagic and Apoptotic Cell Death in Human Prostate Cancer Cells. Cancer Res 2009; 69: 3704-3712. http:// dx.doi.org/10.1158/0008-5472.CAN-08-4344

[53] LI J, LIU R, LEI Y, WANG K, LAU QC, et al. Proteomic analysis revealed association of aberrant ROS signaling with suberoylanilide hydroxamic acid-induced autophagy in Jurkat T-leukemia cells. Autophagy 2010; 6: 711-724. http://dx.doi. org/10.4161/auto.6.6.12397

[54] KIM RH, COATES JM, BOWLES TL, MCNERNEY GP, SUTCLIFFE J, ET AL. Arginine deiminase as a novel therapy for prostate cancer induces autophagy and caspase-independent apoptosis. Cancer Res 2009; 69: 700-708. http://dx.doi. org/10.1158/0008-5472.CAN-08-3157

[55] SY LK, YAN SC, LOK CN, MAN RY, CHE CM. Timosaponin A-III induces autophagy preceding mitochondria-mediated apoptosis in HeLa cancer cells. Cancer Res 2008; 68: 10229-10237. http://dx.doi.org/10.1158/0008-5472.CAN$\underline{08-1983}$

[56] HUANG W, ZHAO H, NI J, ZUO H, QIU L, LI H, et al. The best utilization of D. zingiberensis C.H. Wright by an ecofriendly process. Bioresour Technol 2008; 99: 7407-7411. http://dx.doi.org/10.1016/j.biortech.2008.01.015 


\title{
Supplementary Information
}

\section{Deltonin induced both apoptosis and autophagy in head and neck squamous carcinoma FaDu cell}

\author{
Y. L. XIE ${ }^{1, *}$, M. FAN ${ }^{2}$, R. M. JIANG ${ }^{2}$, Z. L. WANG ${ }^{3}$, Y. $^{3} I^{3}$
}

${ }^{1}$ Department of Otorhinolaryngology, West China Hospital of Sichuan University, Chengdu, Sichuan, China 610041; ${ }^{2}$ Departmen of Otorhinolaryngology, the 7th Hospital of Chengdu City, Chengdu, Sichuan, China 610041; ${ }^{3}$ State Key Laboratory of Biotherapy and Cancer Center, West China Hospital of Sichuan University, Chengdu, Sichuan, China 610041

${ }^{*}$ Correspondence: $y a l i u \_x i e @ 163 . c o m$

Supplementary Figure

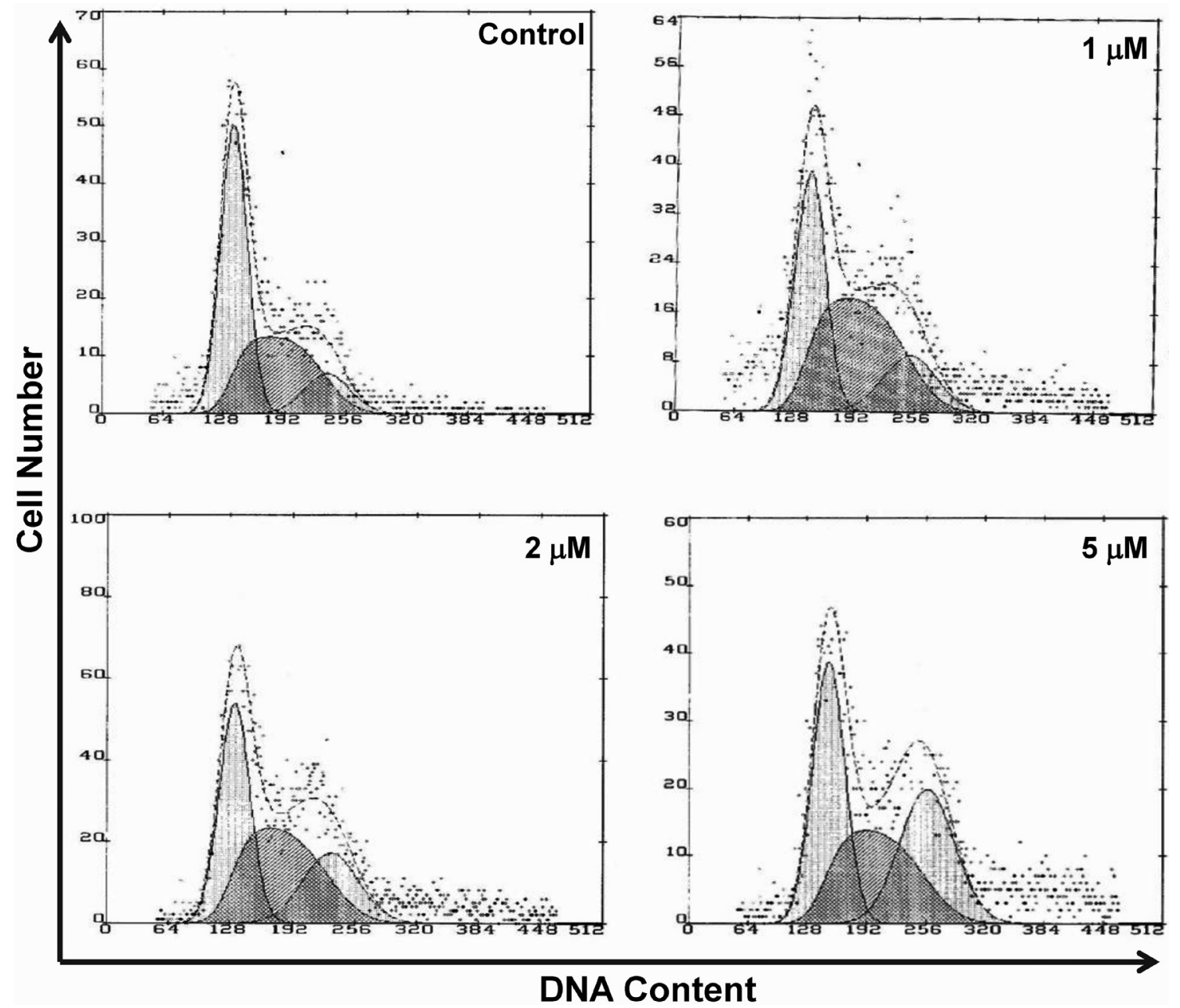

Detonin causes G2/M arrest in FaDu cell after 24 hours exposure to varying doses at 1, 2, 5 uM respectively. 